\title{
Troubled state-building in the DR Congo: the challenge from the margins*
}

\author{
Denis M. Tull \\ German Institute for International and Security Affairs, Ludwigkirchplatz 3-4, \\ Io7Ig Berlin, Germany
}

Email: denis.tull@swp-berlin.org

\section{A B S T R A C T}

This paper examines contentious state-society and centre-periphery relations in the DR Congo and their implications for state-building. Since the 2006 postconflict elections, the state's authority has come under fire in the western province of Bas Congo, where a politico-religious group (Bundu Dia Kongo) has emerged as a serious challenger. Enjoying huge local legitimacy, the group has articulated political grievances that the newly elected central government has violently repressed. As locally perceived, elections are a legitimising tool in the hands of the government to impose its unfettered authority in the name of the state-building project. Furthermore, and backed by donors, the Kinshasa authorities also refuse to implement a wide-ranging decentralisation reform. This has fed disenchantment about post-conflict politics in Bas Congo, boding ill for democratic politics and the prospects of state-building in the DR Congo.

\section{N T R O D U C T I O N}

How are claims to power, legitimacy and resources negotiated in countries emerging from violent conflict? How do central state authorities and local communities at the sub-national level interact with each other in the context of liberal peace? And what is the impact of these interactions on statebuilding? While most observers would probably agree that state-society

* I greatly benefited from the opportunity to present earlier drafts of this article at the University of Oxford, the Paul H. Nitze School of Advanced International Studies (SAIS), Washington, Pomona College, Claremont, and the Laboratoire d'Etudes et de Recherche sur les Dynamiques Sociales et le Développement Local (LASDEL), Niamey. My thanks go to Pierre Englebert, Vincent Foucher, Peter Lewis, Lee Seymour and two anonymous reviewers for their helpful comments. Sarah Biecker and Andrea Sperk provided invaluable research assistance. I am indebted to my interlocutors in Bas Congo and Kinshasa. 
engagement and new forms of social contract are indispensable to build a viable post-conflict order, the burgeoning literature on state reconstruction focuses mostly on external state-builders and their intervention policies (e.g. Doyle \& Sambanis 2006; Fearon \& Laitin 2004). The role and agency of local actors is often ignored, partly because external state-builders tend to construe reconstruction as a top-down process, partly because they assume that donors and domestic actors (invariably described as 'partners') have a shared understanding of reconstruction goals and strategies. ${ }^{1}$ However, the success of state-building depends first and foremost on bargaining and accommodation processes between national elites and groups in society (Migdal 200I). After the withdrawal of external interveners, a stable peace is unlikely to take root if the domestic players cannot agree on the structure of the state and the rules that should regulate public affairs.

This is not to downplay the influence of the international community, whose interference frames transition and post-war politics. For well over a decade, intervention in war-torn countries has been firmly in the grip of the liberal peace paradigm, which essentially stipulates that democratic institutions and procedures help societies to solve political conflict without further violence. However, it is now widely recognised that liberalisation can threaten peace processes by exposing weak political institutions to immense stress (Paris 2004). Precisely because liberalisation opens up space for increased political competition, newly elected rulers in weak states face tremendous pressures from myriad groups in society. The latter perceive the transition from war to democratic politics as a fresh start, a defining moment that may provide a unique opportunity to make claims and to shape the reconstruction project. Demands come not only from supporters of the new regime, but from a wide cross-section of societal groups (political parties, civil society formations, ethnic groups, regions). Frequently, these have long-standing grievances that precede the war by years or even decades. Moreover, some groups may have a perspective different from government elites on the structure and kind of state that is to be built, even if large segments of society may desire an effective state. As a result, the post-conflict arena is a contested field where competing domestic and external interests are played out. The political conflicts shaping these interactions may lead to results that are a far cry from the ambitious visions that external state-builders claim to promote.

The Democratic Republic of Congo (DR Congo) does not escape the difficulties described above. After years of violent conflict, which officially ended in 2002, an arduous transition process (2003-6), and post-conflict 
elections in 2006, the state reconstruction project is in trouble (Trefon 2009). There are scant signs that the elected government of President Joseph Kabila is capable or willing to lead the state-building process, to the frustration of its external partners and local citizens. Economic recovery has barely begun and state structures are still in disarray. For instance, the national army is a force of disorder, committing human rights abuses wherever it is deployed (UN 2009). As a result of the badly compromised situation the 20,500 strong UN peacekeeping Mission in the Congo (MONUC) is bogged down in the country. Following fresh violence in North Kivu province in late 2008, the UN Security Council increased the mission's strength by an additional 3,00o blue helmets. ${ }^{2}$ In late 2009, the number of internally displaced persons had jumped to 2 million, the level of 2000 and $200{ }^{3}{ }^{3}$

North Kivu is not the only trouble spot in the country. ${ }^{4}$ With a population of around 3.2 million people, the western province of Bas Congo is another area where state authority has come under fire. In recent years a politico-religious movement, Bundu Dia Kongo (BDK), has emerged as a challenger to the central state. Riding on a wave of discontent at the marginalisation and exploitation of the province and its people (the BaKongo ethnic group), the BDK has spearheaded protests against the central state since 2006. Over 200 people died during various clampdowns by the government. The violence was paradoxical, because Bas Congo is one of the few provinces that were not touched by the war.

The aim of the present paper is to examine state-society relations in Congo's post-conflict environment and their implications for state reconstruction. It offers a case study of centre-periphery relations between the central government in Kinshasa and the province of Bas Congo, where the BDK has articulated grievances that are almost universally shared. By examining the nature of these protests, their roots and legitimacy, I hope to shed light on the contentious nature of state-society relations in postelection Congo. ${ }^{5}$ I will attempt this by first outlining the nature of the BDK; second by describing the response of the state; third by examining the local legitimacy of the BDK and its agenda; fourth, I will outline the politics of decentralisation reform that brings external actors into the local politics of state-building; finally, the conclusion will provide an analysis of contentious state-building within the larger context of the liberal peace. I will show that external intervention in the Congo, following the blueprint of the liberal peace approach, has had dismal effects. Political liberalisation has provided the government with electoral legitimacy (if vis-à-vis external donors rather than the Congolese people) which has emboldened it to seek unfettered state power, suppressing societal grievances as illegitimate, a process 
that donors have largely tolerated in their desire to see a reconstituted central state. The refusal of the central government to negotiate state authority bodes ill for the long-term prospects of legitimate statehood. ${ }^{6}$

Congo's rulers always considered the Bas Congo area as a restive region. Inhabited by the BaKongo people, the former heartland of the pre-colonial Kongo kingdom (fourteenth-seventeenth century) has given birth to numerous (often messianic) movements against foreign domination. An early example was a prophetic movement led by Kimpa Vita (1684-1706), who sought to restore African Christianity in the face of the claimed white supremacy of missionaries and the political turmoil that had been created by the invasion of the Portuguese in ${ }^{6} 66_{5}$ (Thornton 1998). The colonial period saw the rise of several rural-based anti-colonial messianic movements, the most prominent of which was launched by the prophet and healer Simon Kimbangu in I92 I. Like Kimpa Vita, Kimbangu, a former Baptist catechist, combined elements of Christianity with a sense of BaKongo uniqueness, forging an emancipatory movement with a large following which became officially known as the Church of Jesus Christ on Earth by Simon Kimbangu. The colonial state and the missionary Catholic Church regarded the movement as anti-colonial, xenophobic and ultimately a threat to their supremacy. ${ }^{7}$ During the rest of the colonial period, Kongo cultural identity became more pronounced as its foundation, 'the mythology surrounding the precolonial Kongo kingdom', grew in importance (Young 1976: I82-8). To a fair degree, this was the result of missionary scholars whose writings reflected an admiration for the ancient kingdom that elevated the BaKongo to the status of a special and unique people. These views were passed on to a young generation of BaKongo seminarians, who were eventually to become leaders of Kongo nationalism. These included the founders of the Association des BaKongo (ABAKO), which emerged as a potent challenger to colonial rule during the I950s (Nzongola-Ntalaja 2002: 82). Initially created to affirm the culture of the BaKongo people, it was transformed into a political party. In 1956, ABAKO, then led by Congo's future president Joseph Kasavubu, propelled itself to the forefront of the independence struggle when it became the first Congolese movement to ask Belgium to grant Congo the immediate right to self-government (Lemarchand I96r : 346ff.). Partly due to what was perceived as BaKongo ethnic chauvinism, ABAKO's initial call for a confederation that would include an autonomous Kongo republic was rejected by other ethnic groups. Falling short of its goal of 
outright independence, $\mathrm{ABAKO}$ turned into a fervent proponent of federalism in what was to become the newly sovereign Congolese state (Young 1965: 298-303). The dispute between federalists and advocates of a centralised political system continued after independence, pitting Prime Minister Patrice Lumumba against President Kasavubu and other leaders with a strong regional base.

Mobutu's coup d'état in I965 ended Congo's short-lived experiment with democratic politics. Under the new regime, the BaKongo lost their former influence and hence access to power and patronage networks. Moreover, ethnic associations and political parties were banned as a single-party system was imposed. As a result, the previous 'trend toward affirmation of [BaKongo] identity seemed arrested' (Young i976: 186). Although no open resistance to Mobutu's rule emerged, uneasy relations between Bas Congo and the central state persisted. They found expression in numerous acts of everyday resistance and sabotage. Referring to the mid I970s, Thomas Callaghy observed that opposition sentiments and BaKongo regionalism lay 'just under the surface', leaving regional state officials worrying 'that opposition to Kinshasa now hides behind the numerous new "religious" movements that had sprung up. In other words, resistance now takes the form it did before independence' (Callaghy i984: 278). Also writing in the mid I970s, an astute observer of the country noted that BaKongo identity "probably remains the most intensely held cultural identity in Zaire' (Young I976: I86).

Renewed Kongo agitation came to the fore in the aftermath of Mobutu's overthrow in 1997, although the BDK itself made its entry on the political scene only at the turn of the century. For example, in July 2002 the BDK staged demonstrations in Bas Congo, demanding greater autonomy for the province (IRIN News 26.6.2002). The protests marked the beginning of intensifying Kongo activism that reached its pinnacle in 2008.

Formed in 1986, the Bundu Dia Kongo (Union Mystique Kongo) follows a long tradition of messianic movements in Bas Congo. The BDK is variably described as a political-cultural movement, an ethnically based spiritual and political movement, or a sect. It refers to itself as a 'politicoreligious movement'. Like its historical predecessors, the BKD claims to advance the political, religious and cultural aspirations of the BaKongo people. As one BDK publication notes, 'thus, to some, Bundu Dia Kongo is considered as the Guardian of Kongo Wisdom; others consider Bundu Dia Kongo as the principal union ('syndicat') of Central Kongo and its people; in other words, the nationalist Kongo movement par excellence' (Kongo Dieto 20.7.2007: 2). 
While the defence of Kongo language, rules and customs is a strong rallying point of the $\mathrm{BDK}$, the religious core of its agenda is difficult to discern. According to the BDK, its founder Muanda Nsemi received a calling in I969 by the deity Ne Muanda Kongo, the God-like figure in Kongo spiritual thought, to complete the mission of the prophet Kimbangu, which had been derailed by the latter's successors in the Kimbanguist church. At the heart of BDK beliefs is the conviction that religion presents a cultural core which should reaffirm identity and facilitate liberation from oppression (Wamba-dia-Wamba I999: 219-2I). The BDK considers its faith to be a holistic one, in that religion provides the foundation for politics and science. In this trinitarian conception, religion is the spiritual dimension that informs politics, which in turn guides science to promote the material well-being of the population (ibid.). As a people selected by God, the BaKongo have the task to pioneer spiritual and cultural emancipation for the benefit of all black Africans. The process of emancipation is accompanied by the arrival of messengers sent by God of whom Muanda Nsemi is considered the latest one. Muanda Nsemi considers himself to be the 'great master of Kongo wisdom' (Nlongi'A Kongo).

The emphasis on self-determination (religious or otherwise) notwithstanding, the BDK faith is a syncretistic religion that juxtaposes indigenous spiritual beliefs marked by ancestral power and the invisible world of spirits with elements of Christianity, a result of Kongo's exposure to Christian missionary activities since the fifteenth century. ${ }^{8}$ Thus, religious attitudes among the Kongo are exceedingly ambiguous. On the one hand, aspects of Christian theology have been absorbed into indigenous beliefs; on the other hand, Christianity is contested on account of its foreign origins. According to the BDK, imported Christian religions (like any other imported institution such as foreign languages or alien forms of political organisation) are said to impede emancipation and progress. Consequently, the denunciation of 'colonial churches' by the BDK has led to protracted tensions with the Protestant and Catholic clergy.

In recent years, the political component of the BDK agenda has become more pronounced (September 2008 int.). The BDK officially states that its central political objective is the restoration of the ancient Kongo kingdom within its pre-colonial borders, encompassing parts of present-day DR Congo, Congo-Brazzaville, Gabon and Angola. However, the BDK has expressed various (and sometimes inconsistent) views on this isuse. Recently, BDK leader Muanda Nsemi recommended that the whole of the Central African region should be merged into a single federal state (BBC Monitoring 5.3.2008). At other times, he has alluded to Kosovo as a model for Kongo independence (SouthScan 28.5.2008: 5; BBC Monitoring 5.3.2008). 
Apart from the lofty goal of restoring the pre-colonial Kongo kingdom, the BDK's principal political agenda centres on two sets of grievances. First, the BDK decries the economic exploitation of the province and its BaKongo people by successive central governments. The ire of the BDK is stirred by the perception of unwarranted economic decline and marginalisation despite Bas Congo's enormous potential wealth. The province is not only endowed with mineral resources (diamonds, gold, bauxite), but is the country's only oil-producing area and the site of the Inga hydroelectric barrage. In addition, Congo's only ports, Matadi and Boma, through which nearly all manufactured goods reach Kinshasa, are located in the province. These economic assets make Bas Congo the second largest contributor to the national budget (Liégeois 2008: i I). Mindful of the national revenues that Bas Congo generates, Muanda Nsemi has decried the current political structure as one in which the province is a 'milk cow' that excessively benefits outsiders (La Prospérité I2.12.2007).

Second, the BDK denounces the weak representation of the BaKongo in state institutions and state-owned companies at the provincial level. This is perceived as a deliberate policy by the central government to marginalise the BaKongo and subjugate them to the domination of 'foreigners' (mingizila), i.e. Congolese citizens hailing from outside the province. A case in point is the alleged massive presence of 'foreigners' in public institutions and parastatal organisations such as the Office des Douanes et Accises (OFIDA) and the Office Congolais de Contrôle (OCG). One observer has estimated that BaKongo occupy only io $\%$ of the higher echelons in the provincial administration (Mouflet 2009: 62).

POLITICAL PROTEST AND STATE VIOLENCE IN BAS CONGO, 2007-8

Since about 2005, the BDK has considerably stepped up its visibility by organising protests that have escalated into violent and deadly confrontations with the police. Initially, the protests addressed various economic grievances, including unkept promises by the government to rehabilitate roads and unsatisfied pledges by oil companies and parastatals to hire local personnel (ACP 25.5.2006).

The point of escalation came on 27 January 2007, when the new members of the provincial assembly gathered in Matadi to elect the provincial governor. In the provincial elections of 29 October 2006, Jean-Pierre Bemba's Mouvement pour la Libération du Congo (MLG) and its coalition allies of the Union pour la Nation had won a majority of assembly seats. Therefore the opposition was confident that their candidate would beat the contender of Kabila's ruling party, the Parti du Peuple pour la Réconstruction 
et la Démocratie (PPRD). BDK leader Muanda Nsemi had formed an electoral alliance with the MLC and submitted his candidature as deputy governor of Bas Congo on a joint ticket with Léonard Fuka Unzola, the MLC's candidate for the office of governor. Despite the fact that the Union pour la Nation formed a majority of deputies in the provincial assembly, the PPRD candidate, Simon Mbatshi Batshia, was elected as governor. The polls in Kinshasa and Kasai Oriental, where the national opposition had also a majority of seats, took the same course. In reaction to probably accurate vote-buying allegations, the Bas Congo Appeals Court annulled the election (Kodi 2008: 39ff.). Appeals by the BDK for political negotiations were ignored by the government (Kongo Dieto 21.6.2007). MLC and BDK sympathisers organised a general strike on 3I January, anticipating that Congo's Constitutional Court would overrule the Appeals Court, which it did on i7 February. A police raid on Muanda Nsemi's home in Matadi sparked a violent escalation that spread to other towns in the province, including Boma and Moanda (Reuters I.2.2007; ICG 2007: 10). BDK members killed a dozen police and soldiers in the course of events, while 'excessive force by the security forces and summary executions of BDK members' resulted in the death of I05 people (MONUC 2007: I).

No new direct confrontations occurred until late 2007, but the BDK grew increasingly assertive. It orchestrated a campaign of state defiance, effectively substituting state authority, particularly in its fiefdoms in Luozi and Seke-Banza districts, where state presence was weak. Members of the BDK 'militia', the Makesa ('enforcers' or 'disciples'), intimidated and assaulted state officials, sometimes forcing them to leave localities (La Voixdes-Sans-Voix 27.3.2008; Le Potentiel 22.I.2008). They erected roadblocks, freed fellow BDK members from prisons, and set up local tribunals where harsh sentences were meted out to alleged criminals such as thieves and witches. In at least two cases, BDK members burnt alleged sorcerers alive (MONUC 2008: 8ff.). Fines and floggings were also handed out to people accused of violating Kongo values and customs, including a number of priests, one of them for adultery (Le Potentiel 26.2.2008).

Following a lull of ten months, confrontations between the BDK and the state resumed in January 2008. In Seke-Banza, clashes erupted when BDK members protested against the arrest of two BDK adherents. Four BDK members and one state official were killed (HRW 2008: 75). During the following weeks, the state reacted with a punitive expedition as hundreds of policemen and soldiers were deployed to Bas Congo to crush what Kinshasa described as 'organised resistance' (MONUG 2008: 3). Throughout the province, state agents opened fire on BDK members at BDK temples and roadblocks. Although the BDK members had no arms 
other than 'stones, nuts, sticks and pieces of wood fashioned in the shape of weapons', they sought to defy the security forces with war songs, apparently in the belief that their rudimentary armaments could be magically transformed into lethal instruments (ibid.: 4). An investigation by MONUC noted that 'the excessive use of force' and 'arbitrary executions' led to the death of more than a hundred BDK followers (ibid.: 3). The government called the report 'mendacious', insisting that only twenty-seven people had been killed (HRW 2008: 80). On 22 March, the Kabila government banned the BDK after a cabinet meeting in Matadi. However, occasional acts of sabotage against state institutions have continued.

THE LEGITIMACY OF THE B D K

Given the authoritarian nature of the Kabila government, which rarely permits dissent, it was remarkable that the clampdown on the BDK met with vocal criticism. Vital Kamerhe, then the president of the National Assembly of Kabila's PPRD, described the violent state response an 'error' (BBC Monitoring 5.3.2008). Dinzolele Nzabu, the bishop of Luozi, a diocese whose clergy had been particularly affected by BDK harassment, called upon the government to look for political solutions to the problem: 'After all, if a solution is not found there will be demands made in ways other than through the Bundu Dia Kongo' (IRIN Newes 7.3.2008).

A national parliamentary commission of enquiry, led by deputies from Bas Congo, echoed these sentiments. Its authors described a process of 'state contraction' in Bas Congo as a major cause of the upheavals, explaining that parts of the province suffered from a lack of administration at best; at worst 'the state [has] ceased to exist'. State agents, for want of salaries, were 'condemned to live on the back of the population to survive, thus further feeding popular resentment and the cycle of violence' (Vuemba \& Mpaka 2008: 9). The resulting popular frustration had ushered in a latent revolt that 'the BDK seeks to channel'. (ibid.). Many NGO leaders and civil society activists in Bas Congo share these views, emphatically stressing the local legitimacy of the BDK (September 2008 int.).

But what part of the BDK's agenda appeals to Bas Congo's citizens in particular, even as most sympathisers categorically reject the violent means that the BDK has brought to bear on its struggle? To begin with, the BDK's religious programme seems to be of minor importance. While it is possible, and indeed likely, that a significant number of local citizens adhere simultaneously to Christian churches and BKD spiritual world views, religion has not been pointed out as a significant pull factor by interlocutors. It is even possible that the group's religious dimension may 
impede its mobilisational capacity because $95 \%$ of the BaKongo formally adhere to the Christian faith.

Cultural factors other than religion seem to play a more important role, in particular the widely shared concern over the protection of local values and practices, namely the KiKongo language. Already at the time of independence, ABAKO had drawn substantial strength from local resentment against the expansion of the Lingala language to the detriment of KiKongo in administration and the educational system (Young I965: Ir8). Since then, Lingala has gained further ground in Bas Congo. Moreover, due to the proximity to Kinshasa, trade and migration have led to the introduction of cultural practices that are frequently perceived as a violation of Kongo values, especially among non-youth. As a result, a sense of cultural encroachment is widely felt among the population (September 2008 int.). ${ }^{9}$

The political and economic components of the BDK agenda no doubt strike a powerful chord among the local population, though they do not seem to include the break-up of the DR Congo to resurrect the precolonial Kongo kingdom (September 2008 int.). More relevant are discourses of autochthony which translate, in practical terms, into demands for the privileged recruitment of 'sons of the soil' into public offices and, by consequence, the desire to decrease the number of predatory (so-called) foreigners. So nagging is the real or perceived overrepresentation of nonBaKongo in the public administration that it has entered the local parlance under the phrase of injustices sociales ('social injustices'). This is one of the reasons why the movement is often described as chauvinistic or even xenophobic, a claim that is not entirely convincing. The principle and application of géopolitique, i.e. the notion that locals should be given priority in public job recruitment, became common currency throughout Congo in the early I99os, when the weakening hand of the Mobutist dictatorship permitted a certain freedom of expression. Moreover, autochthony was already a potent discourse at the time of independence in many parts of the country, including Bas Congo, where the provincial government declared that only children of the province would have access to schools (Young 1965: 309). However, it is plain that the introduction of electoral democracy has contributed to the powerful resurgence of discourses of autochthony (Bayart et al. 200i).

These concerns intersect with a discourse on the economic exploitation of Bas Congo's resource wealth by the central government and what is locally perceived as Kabila's clique from eastern Congo. The political mobilisation around shared grievances is facilitated by the salience of local identity. The province constitutes a compact block that is unique in the current landscape of the Congo, combining a relatively homogeneous 
ethnic population with a distinct territory. ${ }^{10}$ This congruence of territory and people has strengthened cultural self-awareness among the BaKongo, and shaped their relation to the central government in Kinshasa. The BaKongo were not integrated in the pre-war patronage networks on which Mobutu relied. This has a significant bearing on Kongo claims to political and cultural autonomy in the post-war period. Thus state politics of exclusion coupled with Bas Congo's political geography explain the BDK's fierce anti-regime discourse. Its popular legitimacy is reflected by the recurrent use of phrases noting that the BDK is 'the voice of the voiceless' and that it 'loudly articulates what everybody thinks but does not dare to say'.

The 2006 election results underscored the popularity of the movement. At the parliamentary elections, the BDK's charismatic leader Muanda Nsemi presented himself as an independent candidate in Luozi district, in which he won with $45 \%$ of the vote, one of the largest majorities achieved by a candidate in the country. The polls also reflected the unpopularity of incumbent President Kabila, who received a mere $13.9 \%$ of the vote in Bas Congo during the first round of the presidential elections. That Jean-Pierre Bemba received $36 \cdot 2 \%$ had probably less to do with his popularity than with the anti-Kabila campaign he had waged and his electoral alliance with Muanda Nsemi. Finally, it is noteworthy that no candidate other than Bemba received significant shares of the vote in the presidential election. For example, Antoine Gizenga of the Parti des Lumumbistes Unifiés (PALU), who came third in the national vote (13\%), received a mere $\mathrm{r} \cdot 8 \%$ of the vote in Bas Congo. Perhaps more surprising, even Justine M'Poyo Kasavubu, the daughter of revered former president Kasavbu, scored only $6 \cdot 6 \%$ of the vote (CEI 2006; Turner 2007: 170).

Congo's new constitution, adopted in 2005, envisions a strongly decentralised political system. A radical break with Congo's long history of pseudo-centralised rule, the reform includes a strong fiscal component which requires the decentralisation of government expenditure and revenue-raising authority to sub-national government structures. Article 175 of the constitution entitles the provinces to retain $40 \%$ of their fiscal revenues. In the past, Congo's provinces had to transfer all of their revenues to the central state before Kinshasa would then redistribute $15 \%$ of the national income back to the provinces. In reality, political expediency and corruption at the centre reduced the transfers to the provinces to breadcrumbs (ICG 2006: I). 
It is not surprising, then, that great hopes were pinned on the reform, notably by the provinces that contribute the largest shares to the national income. These are Kinshasa (38\%), Bas Congo (33\%) and Katanga (20\%) (Liégeois 2008: I I). Given the prospect of raising more in taxes and ceding less to Kinshasa, decentralisation was keenly anticipated in Bas Congo. It was partly for that reason that the BDK vigorously engaged in the provincial and gubernatorial elections. Five years after the referendum and four years after the elections, however, the decentralisation reform still awaits implementation, a fact that many Congolese observers attribute to a deliberate strategy of procrastination by Kinshasa. ${ }^{11}$

But why was fiscal decentralisation included into the constitution in the first place? During the 2005 constitution-writing process, organised under the auspices of the transitional government of national unity, the allocation of power and resources between the centre and the provinces was a contentious issue. ${ }^{12}$ On the hand were those who advocated a federal system, especially the former insurgency Rassemblement Congolais pour la Démocratie (RCD) and its leader Azarias Ruberwa, then one of the four vicepresidents of the transitional government (Le Potentiel 23.3.2005). This was opposed by the Kabila camp and its allies, notably from South Kivu, who argued that federalism could open the door to separatism. In the end a strongly decentralised system emerged as a political compromise. The 2006 elections, which annihilated the RCD politically, changed the balance of power in favour of Kabila, who sought to prevent the decentralisation reform that would deprive the central state of significant revenues.

The country's foreign donors supported the position of the central government. They had noted early on that fiscal decentralisation contained significant macroeconomic risks, i.e. reckless spending by provincial governments. Consequently they argued that large transfers to the provinces should be limited until sufficient capacity was built up at the local level (Towards a Governance Compact 2006: Io). ${ }^{13}$ When the central government published its reform and reconstruction programme, the so-called Contrat de Gouvernance ('Compact') in February 2007, the document reproduced large parts of the prior donor note. The section on decentralisation repeated word for word the position that the donors had formulated six months before. Pending local capacity-building, Kinshasa vowed to 'limit large transfers or retain fiscal resources for an interim period, until fiduciary systems in the provinces are at a minimum acceptable level' (GDRC 2007: 13). As a result, the budget for the fiscal year 2008 showed no trace of fiscal decentralisation. This indicated that the government was determined to act on donors' politically convenient recommendations and their 
argument that the decentralisation process posed a severe threat to macroeconomic stability.

The government even went a step further. Not only did it thwart fiscal decentralisation, it 'reduced fiscal transfers to the provinces from a previous level of $15 \%$ to $6 \%$ ', a unilateral step that donors approvingly described as 'risk mitigation measures' (CGDRC 2007: 9). Hence Congo's new provincial governments, in office since early 2007 , were expected to govern without the necessary legal frameworks and with few or no financial resources. This limbo generated significant tensions between the provinces and Kinshasa. In a show of force, the presidents of ten of Congo's provincial assemblies, led by Bas Congo's François Kimasi, signed the 'Matadi Declaration' on 20 May 2007, requesting the immediate implementation of Article I75 (Liégeois 2008: I3). As pressure from the provinces grew, the government finally entered negotiations with provincial legislators. These led to an agreement to postpone the application of the $40 \%$ formula until January 2008. The delay was to allow more time for appropriate financial and regulatory frameworks to be devised, but no decisions have since been taken (L'Observateur I7.6.2009). Indeed, persistent rumours indicate that the Kabila government wants to revise the constitution to limit or even abolish decentralisation (RFI I7.3.2010).

In summary, because of its own economic (but not necessarily macroeconomic) interests to secure its share of national income, the central government has impeded fiscal decentralisation. Of course, the Kinshasa authorities did not require the advice of donors to conclude that fiscal decentralisation was diametrically opposed to their interests. But the donors provided it with an internationally validated argument to delay and perhaps even revise the decentralisation process that was a central component of the political negotiations that emerged during the transition period. Taken in isolation from the political context, concerns about the economic impact of decentralisation may be justified. ${ }^{14}$ But this is somewhat beside the point. First, to consider Congo's central government as a paragon of 'good governance' and fiscal discipline requires more than a stretch of the imagination (Africa Confidential 8·IO-2009). By the admission of donors, central government budget forecasts sometimes systematically underestimate 'sovereign expenditures', not to mention what donors have prudishly described as the 'excessive use of exceptional procedures' when it comes to budget execution (World Bank 2008: 56). Second, donors miss the fundamentally political point that Congo's envisioned decentralised system is a rallying cry for much of the country and a key pillar in legitimating the new constitution along the country's populous margins. The frustrations in Bas Congo about the non-implementation of Article I75 are 
'shared in the mining provinces of Katanga and the two Kasais and even in the capital where many projects such as road maintenance and water and electricity distribution are at a standstill because of a lack of public investment' (SouthScan 28.3.2008: 4). As the 'Matadi Declaration' suggests, all of Congo's provinces appear to be in favour of fiscal decentralisation, including even those whose revenue streams are expected to significantly decrease under the new arrangement (Le Potentiel 22.5.2007).

Current estimates predict that the provinces of Kinshasa, Katanga and Bas Congo between them would obtain more than $80 \%$ of the total revenues that are to accrue to the provinces under the constitution (Liégeois 2008: $1 \mathrm{I}) .{ }^{15}$ Growing dissatisfaction in the provinces may contribute to centrifugal tendencies that decentralisation reform could help to avert. For the time being, the central government has succeeded in protecting its financial interests, indirectly by aligning with donors who have turned a fundamentally political problem into a technicaladministrative one. In doing so, the Kabila government has deftly used strategies of extraversion: it has employed its ostensibly dependent relationship with external actors (UN, donors) to assert claims on resources and authority in an effort to reinforce its power vis-à-vis its domestic competitors (Bayart 2000).

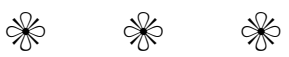

Outside the persistently violent Kivus, more mundane political struggles are unfolding in Congo's post-conflict environment where central state authorities, local communities and donors vie for influence to shape the country's reconstruction project. The upheavals in Bas Congo illustrate the diverging interests between communities and power brokers at the local level, the central government and its foreign backers. Political liberalisation since 2002 has created the conditions for the reinvigoration of historical social formations whose struggle is essentially a 'critique of the centre'. ${ }^{16}$ The case of Bas Congo indicates that the trouble with state-building is twofold. First, implicit to state-building are efforts to bolster state power by helping the central government to reclaim its alleged prerogatives and to revert the fragmentation of state power. As the heated debate over the decentralisation reform suggests, this is a strongly contested project. Nowhere in the Congo is this more obvious than in Bas Congo, where the exceptionally strong cultural identity of the BaKongo people has facilitated the rise of a movement that has vigorously confronted the central government and its claims to authority. The strength of the BDK derives 
from its significant historical depth and local legitimacy. Extending over decades if not centuries, the BDK is just the most recent incarnation of long-standing political currents among the BaKongo people.

Second, the Bas Congo case suggests that the presently preferred strategy towards state-building, the liberal peace agenda, creates its own problems and contradictions. State-building, defined as centralisation of power, sits uneasily with democracy when, for all practical purposes, its exercise is limited to elections. The timing of the BDK protests was certainly no coincidence as the group advanced its grievances when Congo had adopted a formally democratic dispensation for the first time since independence. From the point of view of the BDK, the transition to democracy opened up the political space to participate in politics, and the group sought to seize the new democratic opportunities to advance its agenda. However, electoral foul play and ultimately the state's suppression of almost universally shared grievances among Bas Congo's population has fed local disenchantment about the state, post-war 'democratic politics' and its alleged benefits ('liberal peace'). As locally perceived, elections have served as a legitimising tool in the hands of the government to impose its unfettered authority in the name of the state-building project. This is not in the least to imply that the way of doing politics of local or regional power-brokers (elected or otherwise) does differ fundamentally from Kabila's. Indeed, it is rare that the political logics on both levels are not closely intertwined. Shrewd and ruthless calculations dominate sub-national politics everywhere in the country, and one would be hard-pressed to identify a province or a local constituency where the politics of the belly do not constitute an axiomatic law. In three years, for example, half a dozen governors, vice-governors or presidents of provincial assemblies have resigned or been subject to impeachment on allegations of embezzlement of public funds, including François Kimasi, the president of the Provincial Assembly in Bas Congo. ${ }^{17}$ Rather, it is to say that the tensions between the centre and the provinces add another layer of political conflict to Congo's political landscape. This warrants attention because it speaks to the protracted issue of the central state's weak political legitimacy. It would be an illusion to think that this weakness will be overcome by the increased provision of public goods.

Assuming that state-society engagement is a building block of legitimate and effective statehood, the prospects for Congo's state-building project look bleak. ${ }^{18}$ Emboldened by its electoral legitimacy, the Kabila government has shown no sign that it is prepared to negotiate its authority, an observation that applies not only to Bas Congo but also to North Kivu, where after 2006 the government staged several fruitless attempts to crush 
remaining insurgent groups before successive defeats forced it into negotiations with the rebels. Rumours suggesting that constitutional revisions are under way, which among other things would end presidential term limits and abrogate the independence of the judiciary, are only the latest signs of unreconstructed authoritarianism (Le Potentiel 23.9.2009). I argue that a part of the explanation for this drift rests with the nature of international intervention politics in the Congo, more specifically the liberal peace and its core element, elections. As in other countries emerging from conflict, external actors considered elections 'a key element in the transition from a post-conflict to a truly democratic, unified and stable State' (UN 2005：I).

This lofty discourse does not hide more pragmatic short-term imperatives. The elections were necessary to create a government that Congo's external backers desperately needed to promote post-conflict state-building. Therefore success required a legitimate(d) local partner. The feverish pushing for the polls suggested that the ownership of the elections lay more with external forces than with Congolese actors. This did not escape Congo's political contenders, and it had implications for the post-election chessboard. Since assuming office, the Kabila government has made known its conviction that thanks to its electoral legitimacy it is (and should be) insulated from criticism and accountability, both from inside and outside, making political reform all but impossible (Englebert 2009). The argument seems to have been accepted by the international community. ${ }^{19}$ After all, the government is the product of the political engineering process that the international community had organised. What is more, Kabila is keenly aware that donors and assorted outsiders need the government as much, or even more, than the government needs its outside supporters. Because the international community had invested so much in the Congolese peace process, sanctioning the abusive government and some of its egregious policies was apparently not an option (Willame 2007: I7Iff.). This inadvertently provided the Kabila government with free rein to pursue authoritarian politics that have progressively led to the closure of political space. This has given the impression that for the international community political liberalisation had outlived its usefulness after an elected government had been put into place. In other words, the post-election phase marked the departure from pro-democracy discourse to realpolitik. Donors were prepared to go to great lengths to lend their support to the government, in the process reinvigorating the grievances of disenchanted segments of society, including in Bas Congo. This suggests that the internationally legitimating function of elections can far exceed their utility in legitimating new governments domestically. 
NOTES

I. For a notable exception see Pouligny 2006. On the divergent views of donors and the leaders in countries of intervention see Englebert \& Tull 2008.

2. To the consternation of the international community, however, President Kabila asked the UN to begin MONUG's drawdown in mid 2010 and to complete the withdrawal before the national elections scheduled for 20I I. A reluctant UN Security Council decided in May 20Io to withdraw 3, Ooo blue helmets. See Tull 20 io.

3. Internal displacement reached its peak of 3.2 million in 2002 , before the number dropped to its lowest in 2006 (I.I million).

4. In addition, clashes between ethnic militias near Dongo (Equateur province) killed 270 people and displaced 200,000 in 2009/IO. In April 20I0, this seemingly localised conflict spread as one insurgent group briefly occupied parts of the provincial capital of Mbandaka.

5. This paper is based on thirty-eight interviews conducted by the author in three towns in Bas Congo (Kimpese, Boma and Matadi) during three weeks of fieldwork in September 2008. Most interviewees were members of local NGOs and civil society groups. Four members of the BDK were also interviewed.

6. However, successive military defeats at the hand of an insurgent group in North Kivu forced the government in 2009 to strike a bargain with the rebels.

7. Following a campaign of civil disobedience, the colonial authorities threw Kimbangu in prison, where he died in I95I.

8. See also Bockie 1993 and the works of Wyatt MacGaffey (e.g. I983, I986).

9. It is further fed by the fact that KiKongo is recognised as one of Congo's four national languages.

I0. It is noteworthy that Bas Congo will retain that unique status once the territorial reconfiguration of the Congo is implemented, which foresees twenty-six provinces, i.e. a number of provinces will be split to create new provinces. In this new dispensation, Bas Congo will be the largest mono-ethnic electoral entity in the country. See DfID 2007: 45 .

I I. See for example the interview with Jean Omasombo in La Libre Belgique I4.4.20Io.

I2. On the interests that shaped the constitution-writing process see 'Missing a basic law', Africa Confidential $\mathrm{I} 5 \cdot 4 \cdot 2005$.

13. See also IMF 2007: I7 and World Bank 2007: iv.

I4. The new constitution stipulates that the number of provinces is to increase from the present eleven to twenty-six. This is also opposed by the World Bank. See 'Découpage en 26 provinces autonomes contre I I actuellement', Le Palmarès 21.7.2009.

I5. It should be noted that an 'Equalisation Fund' is to be created that would absorb io \% of national revenues. The money from this account is to finance investments in the poorer provinces.

I6. This phrase is borrowed from de Waal 2007: 4.

I7. It needs to be emphasised that impeachments may often be themselves the result of corruption or political manoeuvres, i.e. they do not necessarily reflect the emergence of a healthy democratic culture.

I8. This does not preclude bargaining processes at the very local level; see Vlassenroot 2008.

I9. It seems that donors' predominant concerns are the mining contracts that the Congolese government has signed with Chinese companies. See 'IMF to study Congo's China deal before any accord', Reuters I.7.2008.

\section{R E F E R E N C E S}

Bayart, J.-F. 2000. 'Africa in the world: a history of extraversion', African Affairs 99, 395: 217-67.

Bayart, J.-F., P. Geschiere \& F. Nyamnjoh. 200ı. 'Autochtonie, démocratie et citoyenneté', Critique Internationale I0: 177-94.

Bockie, S. I993. Death and the Invisible Powers: the world of Kongo belief. Bloomington, IN: Indiana University Press.

Callaghy, T. M. I984. The State-Society Struggle: Zaire in comparative perspective. New York: Columbia University Press.

Commission Electorale Indépendante (CEI). 2006. Résultats provisoires des élections présidentielles $\left(I^{\text {er }}\right.$ tour $)$ par province. Kinshasa: CEI.

Consultative Group for the DR Congo (CGDRG). 29-30·II·2007, main discussion paper, Paris. 
Department for International Development (DfID). 2007. Aid and Conflict in the DR Congo: strategic conflict assessment. London: DfID.

Doyle, M. W. \& N. Sambanis. 2006. United Nations Peace Operations: making war and building peace. Princeton, NJ: Princeton University Press.

Englebert, P. 20og. Africa: unity, sovereignty, and sorrow. Boulder, CO: Lynne Rienner.

Englebert, P. \& D. M. Tull. 2008. 'Post-conflict reconstruction in Africa: flawed ideas about failed states', International Security 32, 4: 106-39.

Fearon, J. D. \& D. D. Laitin. 2004. 'Neotrusteeship and the problem of weak states', International Security $28,4: 5^{-43}$.

Government of the Democratic Republic of Congo (GDRC). 2007. Contrat de Gouvernance (CDG) MarsDécembre 2007. Kinshasa.

Human Rights Watch (HRW). 2008. "We Will Crush You": the restriction of political space in the Democratic Republic of Congo. New York: HRW.

International Crisis Group (ICG). 2006. Escaping the Conflict Trap: promoting good governance in the Congo. Nairobi/Brussels: ICG.

ICG. 2007. Congo: consolidating the peace. Nairobi/Brussels: ICG.

International Monetary Fund (IMF). 2007. Democratic Republic of the Congo: 2007 article IV consultation. Staff Report. Washington, DC: IMF.

Kodi, M. 2008. Corruption and Governance in the DRC during the Transition Period (2003-2006). Pretoria: Institute for Security Studies.

Lemarchand, R. 196r. 'The bases of nationalism among the Bakongo', Africa 3, 4: 344-54.

Liégeois, M. 2008. La Décentralisation en RD Congo: enjeux et défis. Brussels: GRIP.

McGaffey, W. 1983. Modern Kongo Prophets: religion in a plural society. Bloomington, IN: Indiana University Press.

McGaffey, W. 1986. Religion and Society in Central Africa: the BaKongo of Lower Zaire. Chicago, IL: University of Chicago Press.

Migdal, J. S. 2001. State in Society: studying how states and societies transform and constitute each other. Cambridge University Press.

MONUC. 2007. Mission d'Enquête au Bas-Congo. Kinshasa: United Nations.

MONUC. 2008. Special Inquiry into the Bas Congo Events of February and March 2008. Kinshasa: United Nations Human Rights Division.

Mouflet, V. 2009. 'Le Bas-Congo, aux marges de l'agenda international: angles morts sur les émeutes de 2008', Afrique Contemporaine 232: 57-74.

Nzongola-Ntalaja, G. 2002. The Congo from Leopold to Kabila: a people's history. London: Zed.

Paris, R. 2004. At War's End: building peace after civil confict. Cambridge University Press.

Pouligny, B. 2006. Peace Operations Seen from Below: U.N. missions and local people. Hartford, CT: Kumarian Press.

Thornton, J. K. 1998. The Kongolese Saint Anthony: Dona Beatriz Kimpa vita and the Antonian movement. Cambridge University Press.

Towards a Governance Compact in DRC: from elections to good governance. 6.7.2006, background paper prepared on the basis of an informal donor session, Brussels.

Trefon, T., ed. 2009. Réforme au Congo: attentes et désillusions. Paris: L'Harmattan.

Tull, D. M. 2010. When they Overstay their Welcome: UN peacekeepers in Africa. Berlin: Germany Institute for International and Security Affairs.

Turner, T. 2007. The Congo Wars: conflict, myth and reality. London: Zed.

United Nations (UN). 2005. Special Report of the Secretary-General on Elections in the Democratic Republic of the Congo. New York: UN.

UN. 2009. Twenty-Eighth Report of the Secretary-General on the United Nations Organization Mission in the Democratic Republic of Congo. New York: UN.

Vlassenroot, K. 2008. 'Négocier et contester l'ordre public dans l'est de la République Démocratique du Congo', Politique Africaine in : 44-67.

Vuemba, J.-C. \& R. Mpaka. February 2008. Rapport de mission parlementaire: information et pacification dans le district du Bas-Flewve et à Luozi, I2 January - 2 February 2008. Luozi.

Waal, A. de. 2007. Sudan: what kind of state? What kind of crisis?, Crisis States Research Centre, Occasional Paper 2, London.

Wamba-dia-Wamba, E. I999. 'Bundu dia Kongo: a Kongolese fundamentalist religious movement', in T. Spear \& I. N. Kimambo, eds. East African Expressions of Christianity. Oxford: James Currey, 215-2I. 
Willame, J.-C. 2007. Les 'Faiseurs de la Paix' au Congo: gestion d'une crise internationale dans un etat sous tutelle. Brussels: GRIP.

World Bank. 2007. Country Assistance Strategy for the DR Congo. Washington, DC: World Bank.

World Bank. 2008. Democratic Republic of Congo Public Expenditure Review. Washington, DC: World Bank.

Young, C. 1965. Introduction à la Politique Congolaise. Brussels: CRISP.

Young, C. 1976. The Politics of Cultural Pluralism. Madison, WI: University of Wisconsin Press.

\section{Agencies $\&$ newspapers}

Africa Confidential, London; Agence Congolaise de Presse (ACP), Kinshasa; BBC Monitoring, Reading; IRIN News; Kongo Dieto, Bundu Dia Kongo Information Department, Kinshasa; La Libre Belgique, Brussels; L'Observateur, Kinshasa; Le Palmarès, Kinshasa; Le Potentiel, Kinshasa; La Prospérité, Kinshana; Reuters, Frankfurt am Main; Radio France International (RFI), Paris; SouthScan, Washington DC; La Voix-desSans-Voix, Kinshasa. 